\title{
Immune effects of probiotics
}

\author{
By Agnes E. Wold
}

\begin{abstract}
Twenty papers concerning the effects on the immune system of ingestion of probiotic bacteria in humans have been reviewed. Several studies report that intake of probiotics stimulate cellmediated immune effector functions. Thus, enhanced production of interferon- $\gamma$ by blood cells, enhanced phagocytosis by polymorphonuclear leukocytes (PMN) and to a lesser extent monocytes, and enhanced expression of complement receptors on PMNs are effects quite consistently seen in subjects consuming probiotic bacteria. It is likely that this is the result of probiotic bacteria being taken up across the small intestinal mucosa and being ingested by macrophages, leading to the production of cytokines and other mediators stimulating cell-mediated immunity.

Probiotics have also been suggested to function as adjuvants, i.e. agents that increase immune responses to other antigens administered concomitantly. However, responses to vaccination are generally only mildly increased during probiotic consumption and most likely depend on the occurrence of cross-reactive antibodies that are induced by the probitic bacteria but also bind to structures on unrelated antigens. A few studies have tested the clinical effect of probiotics on allergy, but to date no effect has been convincingly proven.

In conclusion, probiotic treatment could be beneficial in conditions where stimulation of cellmediated effector functions is desired. Key words: clinical studies, humans, immune, probiotics
\end{abstract}

\section{Introduction}

Microbes and other particles that are ingested are taken up in the Peyer's patches. These are lymphoid nodules in the wall of the small intestine containing macrophages and other antigenpresenting cells, B cells and T cells. The Peyer's patches serve as inductive sites for mucosal immune responses. Usually, invasive and otherwise pathogenic microbes are the best inducers of immunity, which is probably due to their superior capacity to multiply in the intestine and penetrate across the mucosal barrier, a prerequisite in order to stimulate the immune system (1). However, dead microbes also induce immunity, provided that they are given in high enough doses $(2,3)$.

Animal experiments document that the commensal microflora is the major stimulus to the gut immune system and is also a potent regulator of the innate immune system (reviewed in 4). The presence in healthy individuals of break-down products of bacteria in spleen macrophages and their secretion in the urine, is testimony to the constant influx of bacterial products across the mucosal surfaces $(5,6)$.

The small intestine, where the Peyer's patches are situated, is relatively sparsely populated by bacteria (from $10^{3} \mathrm{CFU} / \mathrm{g}$ in the proximal duodenum to between $10^{5}$ and $10^{8}$ in the distal ileum). Thus, if one assumes that the bacterial population density in the small intestine is $1 / 10000$ of that in the colon, the entire small intestine probably harbours no more that $10^{10}$ bacteria. It is thus feasible that ingestion of some $10^{10}-10^{11}$ bacteria daily can have a significant impact on the gut immune system, even if this dose

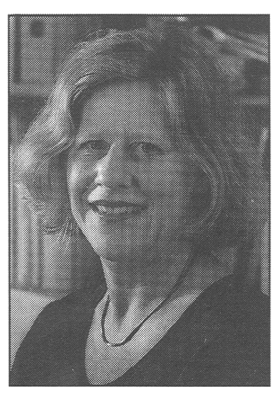

Agnes Wold, Assoc. Prof., Dept of Clinical Immunology, Göteborg University, Sweden.

E-mail: agnes.wold@immuno.gu.se

The article is based on a lecture presented at the symposium "Probiotics and prebiotics - scientific evidence in humans as a basis for health claims", 1415 November 2000, arranged by SNF Swedish Nutrition Foundation. is small compared to the $10^{14}$ bacteria inhabiting the colonic microflora. Since the Peyer's patches are designed to take up any particles present in the small intestinal lumen, probiotic bacteria will probably not have to colonise in order to stimulate immune effector functions.

\section{Aim}

In spring 2000 an ad hoc committee of Swedish scientists was formed jointly by the Expert Group of Diet and Health of the National Food Administration and the Research Board of SNF Swedish Nutrition Foundation. The task was to review and evaluate human clinical studies on the health effects of probiotics and prebiotics (7). This paper examines clinical trials concerning immune effects of probiotics. References were collected from Medline and from available reviews on clinical immune effects of probiotics, until September 2000.

Some studies are listed in Table 1 on pages 79-85. Those references are marked $(*)$ in the following text and in the reference list. Articles are evaluated in the Tables (column 13) as +low quality; ++ medium quality; +++ high quality.

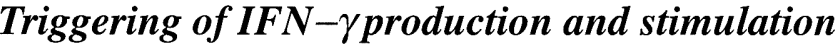 of cell-mediated immune effector functions}

Several studies report that ingestion of probiotic bacteria or fermented milk products triggers spontaneous $\left(8^{*}\right)$ and enhances mitogen-induced $\left(9 *, 10^{*}\right)$ production of interferon $-\gamma$ by blood leukocytes. The cells responsible for the interferon production have not been identified in these studies, but are likely to be NK cells and/or T cells $(11,12)$. Enhanced production in blood cells of the antiviral enzyme 2'-5'A synthase has been observed in volunteers consuming yoghurt $(13 *)$. This enzyme is induced by interferons. One study reports increased production of interferon- $\alpha$ after PHA stimulation of blood leukocytes in persons consuming lactobacilli, but the IFN- $\alpha$ levels in both groups were very low $\left(14^{*}\right)$

A single study reports increased levels of IFN- $\gamma$ in serum after intake of yoghurt supplemented with lactobacilli and streptococci $\left(15^{*}\right)$, whereas other studies are negative $\left(8^{*}, 13^{*}\right)$. 
Changes in blood cell population levels were also noted in the former study, which is not seen in other studies $\left(9^{*}, 16^{*}\right)$. The exceptionally high dose given $\left(3 \times 10^{12} \mathrm{CFU} /\right.$ day) may be one explanation for the deviating results of this study.

Intake of probiotics has also been shown to affect blood lymphocytes so that they display enhanced IL-2 responses after stimulation of $\mathrm{T}$ cell mitogens $\left(8^{*}, 9^{*}, 10^{*}\right)$. There are, however, also studies that report lack of effect on IFN-yor IL-2 production after ingestion of probiotics, e.g. Lactobacillus casei strain Shirota $\left(17^{*}\right)$ or yoghurt $\left(18^{*}\right)$. The volunteers in the former study had remarkably high counts of lactobacilli in faeces prior to the study $\left(10^{7} \mathrm{CFU} / \mathrm{g}\right)$, while the participants in the latter study showed high spontaneous activation of their blood lymphocytes.

Ingestion of probiotic bacteria enhances the phagocytic capacity of blood polymorphonuclear leukocytes $\left(14^{*}, 16^{*}, 19^{*}\right)$ triggers respiratory burst $\left(9^{*}, 19^{*}\right)$, and increases their expression of receptors involved in phagocytosis, especially complement receptor 3 (CR3) $\left(20^{*}, 21^{*}\right)$. Blood monocytes are similarly affected, although to a lesser extent $\left(16^{*}, 20^{*}\right)$.

This stimulation of cell-mediated effector functions (IFN- $\gamma$ ) production and enhanced phagocyte function) probably results from the production of immune-stimulating cytokines and other mediators when probiotic bacteria interact with monocytes/ macrophages in the Peyer's patches, intestinal mucosa, or other sites. Lactobacilli, as well as other Gram-positive bacteria, are very efficient in inducing the production of IL-12 (22,23). IL-12 is the major stimulator of cell-mediated immune effector functions. Thus, IL-12 stimulates IFN- $\gamma$ production in T cells and NK cells and increases their cytotoxic potential (24). Needless to say, many other cytokines and mediators will be triggered when probiotic bacteria interact with macrophages and other cells in the innate immune system, many of which might be involved in the enhancement of phagocytic function after intake of probiotics.

Although many types of probiotic bacteria - Lactobacillus rhamnosus, Lactobacillus johnsonii and yoghurt cultures appear to activate phagocytes, $\mathrm{He}$ and coworkers compared upregulation of complement receptors on blood phagocytes after feeding L. rhamnosus and Lactococcus lactis and found the latter to be superior $\left(21^{*}\right)$. Tentatively, this might be explained by the induction of relatively large amounts of IL-10 by $L$. rhamnosus compared to other Lactobacillus species (22). IL-10 is a macrophage-derived cytokine that down-regulates IFN- $\gamma$ production, thus opposing the action of IL-12 on T cells and NK cells (25).

\section{Local IgA responses}

Probiotic bacteria, like any other microbes that are taken up from the intestinal lumen, will induce a specific immune response to themselves. In addition, microbes also stimulate production of antibodies that have other, unknown, specificities $(26,27)$. The function of such non-specific antibodies is unknown, as are the mechanisms for their induction. However, it is conceivable that ingestion of probiotics by this mechanism could stimulate, in a non-specific manner, enhanced production of secretory IgA on mucosal surfaces, or serum IgA in the circulation.

Four studies have examined the local production of secretory IgA in response to probiotic treatment. Fukushima et al. reported increased levels of total faecal IgA and faecal IgA anti-poliovirus antibodies after feeding formula supplemented with bifidobacteria (28). The infants had been vaccinated with attenuated poliovirus as part of the regular vaccination scheme which had been completed several months before the study. Statistically significant differences in faecal IgA levels were, however, only demonstrated at one time point but not the others. Moreover, it cannot be ruled out that the survival of secretory $\operatorname{IgA}$ in the intestinal milieu is affected differences in faecal $\mathrm{pH}$, water content or transient time, factors that may all be affected by ingestion of bifidobacteria. Quantification of immunoglobulins in faeces has been strongly discouraged due to large variations in recovery rates between samples (29).

In an elegant study, Marteau et 1 . used jejunal perfusion to investigate whether ingestion of fermented milk containing a Lactobacillus johnsonii strain would alter secretion of IgA or other immunoglobulin isotypes in the small intestine. No increased secretion of $\operatorname{IgA}$ (nor of $\operatorname{IgG}$ or $\operatorname{IgM}$ ) was noted (30*). Lactating mothers who were given $L$. rhamnosus $\mathrm{GG}\left(4 \times 10^{10}\right.$ $\mathrm{CFU} /$ day) did not increase their milk IgA levels $\left(31^{*}\right)$.

In conclusion, evidence for increased local $\operatorname{IgA}$ responses in humans after probiotic intake are still awaiting.

\section{Serum IgA}

Two studies $\left(30^{*}, 32^{*}\right)$ report an increase in serum $\operatorname{Ig} \mathrm{A}$ concentrations of approximately $10 \%$ after consumption of the same probiotic bacterial strain, Lactobacillus johnsonii La1 from the Nestlé company. Although other studies show no increase of serum $\operatorname{IgA}$ concentrations after intake of other probiotic strains or yoghurt products $\left(9^{*}, 17^{*}\right)$, it is possible that this particular strain is more efficient than others in inducing serum IgA. Serum IgA is produced in the bone marrow and is regulated independently from the mucosal IgA system.

\section{Adjuvant function}

Adjuvants are substances that enhance immune responses to other, unrelated antigens, with which they are mixed. Adjuvants function by stimulating antigen presentation to $\mathrm{T}$ cells by enhancing the production of $\mathrm{T}$ cell-stimulating cytokines and expression of accessory molecules by antigen-presenting cells. This is the basis for the fact that microbial antigens, which possess conserved structures with capacity to activate monocytes, macrophages and dendritic cells, are very good immunogens. In contrast, food proteins have no capacity to activate the antigen-presenting cell and are poorly immunogenic. It has been suggested that lactobacilli may function as adjuvants, which means that they would enhance immune responses to other, unrelated, antigens administered concomitantly.

Several studies have examined the antibody response to peroral $\left(9^{*}, 32^{*}, 33^{*}\right)$ or systemic $\left(9^{*}\right)$ vaccination, or to natural infection $\left(34^{*}, 35^{*}\right)$ or dietary components $\left(36^{*}\right)$ in volunteers consuming probiotic bacteria and their controls. No increased reponse to oral poliovirus or parenteral pneumococcal vaccination was noted in one study $\left(9^{*}\right)$, but Link-Amster et al. reported that the serum $\operatorname{IgA}$ antibodies in serum to Salmonella typhi increased $4.1 \mathrm{x}$ after vaccination in volunteers consuming lactobacilli, compared with a $2.5 \mathrm{x}$ increase in the control group $(\mathrm{p}=0.04)(32 *)$. On the other hand, the control group responded better in saliva than the group consuming probiotics. Similarly, the IgA response to rotavirus in serum 3 weeks after rotavirus infection was 2.3 times higher in a group of children consuming L. rhamnosus than in control children $\left(35^{*}\right)$, but in another study by the same authors $\left(34^{*}\right)$, there was no difference in serum antibody responses between the groups. In a study of the response to vaccination with rotavirus, seroconversion was more frequent in volunteers consuming lactobacilli than in controls, but the definition of "seroconversion" was an increase of $>20 \%$ in antibody levels (33*). At least a doubled or tripled antibody response is more generally accepted as a definition of seroconversion. Similarly, studies that have used enumeration of antibody-producing cells in blood as a measure of the immune response have employed an abnormally low cut-off levels for defining "responders" $\left(0.5\right.$ antibody-secreting cell per $10^{6}$ blood cells) $\left(21^{*}, 35^{*}\right)$. Usually, at least 5 or 10 antibody-producing 
cells $/ 10^{6}$ blood cells is considered a relevant response to vaccination, whereas the response to natural infection is usually 10-100 times higher (37-40).

It is important to realize that the presence of cross-reacting antibodies, induced by and against the probiotic strain, but reacting with the vaccine strain, does not mean that the probiotic displayed an adjuvant effect. Antibodies to lactobacilli may cross-react with structures on $E$. coli, which are not at all closely related (41). In accordance, increased amounts of antibodies to completely unrelated antigens were noted in one study of volunteers consuming probiotics $(32 *)$.

Thus, in order to prove an adjuvant effect, sera must be absorbed with the probiotic bacteria before being assayed for antibody activities against the vaccine strain. No study has employed such measures. It can be concluded that adjuvanticity of probiotic bacteria on immune responses to infection or vaccination has not been proven. Actually, it could be quite hazardous if ingestion of yoghurt or other probiotic products stimulated immune responses to completely unrelated antigens, which could include autoantigen, food proteins etc. However, animals reared devoid of bacterial flora respond equally well, or better, to vaccination, food antigens and colonisation by microbes, compared to animals that already harbour a full microflora (42). This speaks against an adjuvant effect by intestinal bacteria on immune responses to unrelated antigens.

\section{Effects on allergies}

Three studies have examined the effect of consumption of probiotics on asthma and allergic symptoms. Majamaa and Isolauri $\left(31^{*}\right)$ gave an extensively hydrolysed formula containing L. rhamnosus GG to infants with atopic eczema and clinical evidence of cow's milk allergy, control infants received the hydrolysed formula without bacteria. The severity of the atopic eczema, as measured by SCORAD, was improved more in the GG group than in the control group after one month's feeding, but the former group had a higher value before initiation of treatment. After treatment, the median SCORAD value was, in fact, 19 in the control group and 20 in the GG group. One may, thus, conclude that the study failed to demonstrate any clinical effect of the treatment. In the GG group, faecal $\alpha$-1-anti-trypsin concentrations and TNF- $\alpha$ concentrations fell sharply after treatment, whereas serum ECP was unaltered. This is an interesting indication of a reduced intestinal inflammatory response, but it needs to be confirmed that alterations in the intestinal contents due to the presence of lactobacilli (lowered $\mathrm{pH}$, increased water content, increased content of organic acids) simply have not rendered the environment more hostile to the survival of these molecules.

Trapp and coworkers $\left(18^{*}\right)$ performed a very large study in which young and elderly people consumed yoghurt, inactivated yoghurt, or no yoghurt, for one year. The authors found fewer symptoms of nasal allergies and lower total serum IgE levels in volunteers who consumed either of the yoghurt preparations than in the control group. Unfortunately, randomisation was only performed between people drinking live or inactivated yoghurt, while the non-yoghurt control group consisted of people not wanting to consume yoghurt products. It cannot be excluded that the latter individuals have a less healthy lifestyle or are less willing to medicate adequately than the volunteers who complied with taking yoghurt. The differences between the groups was present in the first sample already and persisted throughout the one-year study period. It is therefore possible that the differerences were already present before treatment.

Wheeler and coworkers $\left(10^{*}\right)$ gave yoghurt with live lactobacilli to 15 adults with moderate asthma and yoghurt without lactobacilli for another month in a double-blind crossover study. No differences in spirometric functions could be detected relating to the consumption of lactobacilli.

In conclusion, more studies are needed to elucidate whether probiotics might have beneficial clinical effects on established allergy. This is an extremely dynamic area, and more data can be expected within the next few years.

\section{Conclusion}

In conclusion, there is relatively good evidence that intake of probiotics transiently activates cell-mediated immune effector functions, such as interferon $-\gamma$ production and phagocyte function. An adjuvant effect vis-à-vis unrelated antigens administered concomitantly has not been proven, and the clinical effects on allergy have been too little studied to date in order for any conclusions to be drawn.

\section{REFERENCES}

\section{*References listed in Tables (pages 78-85)}

1. Hohmann A, Schmidt G, Rowley D. Intestinal and serum antibody responses in mice after oral immunization with Salmonella, Escherichia coli, and Salmonella-Escherichia coli hybrid strains. Infect Immun 1979; 25:27-33.

2. Ogra PL, Karzon DT, Righthand F, MacGillivray M: Immunoglobulin response in serum and secretions after immunization with live and inactivated poliovaccine and natural infection. N Engl J Med 1968; 279: 893-900.

3. Moreau MC, Ducluzeau R, Guy-Grand D, Muller MC: Increase in the population of duodenal immunoglobulin A plasmocytes in axenic mice associated with different living or dead bacterial strains of intestinal origin. Infect Immun 1978;21:532-9.

4. Wold AE, Adlerberth I. Pathologic effects of commensalism. In: Nataro JP, Blaser MJ, Cunningham-Rundles S, editors. Persistent Bacterial Infections: ASM Publishing Co.2000;pp115-144.

5. Hoijer MA, Melief MJ, van Helden-Meeuwsen CG, Eulderink F, Hazenberg MP: Detection of muramic acid in a carbohydrate fraction of human spleen. Infect Immun 1995;63:1652-7.

6. Johannsen L, Krueger JM: Quantification of diaminopimelic acid in human urine. Adv. Biosci. 1988:68:445-9.

7. Andersson H, Asp NG, Bruce A, Roos S, Wadström T, Wold AE: Health effects of probiotics and prebiotics. A literature review on human studies. Scand J Nutr 2001;45:58.75.

8.* Halpern GM, Vruwink KG, van der Water J, Keen CL, Gershwin ME: Influence of long-term yoghurt consumption in young adults. Int $\mathbf{J}$ Immunother 1991;VII:207-10.

9.* Wheeler JG, Bogle ML, Shema SJ, Shirrell MA, Stine KC, Pittler AJ, et al: Impact of dietary yogurt on immune function. Am J Med Sci 1997;313:120-3.

10.*Wheeler JG, Shema SJ, Bogle ML, Shirrell MA, Burks AW, Pittler A, et al: Immune and clinical impact of Lactobacillus acidophilus on asthma. Ann Allergy Asthma Immunol 1997;79:229-33

11. Haller D, Blum S, Bode C, Hammes WP, Schiffrin EJ: Activation of human peripheral blood mononuclear cells by non pathogenic bacteria in vitro: evidence of NK cells as primary targets. Infect Immun 2000;68:752-9.

12. Hessle C, Andersson B, Wold AE: Gram-positive bacteria are potent inducers of monocytic interleukin-12 (IL-12) while gram-negative bacteria preferentially stimulate IL-10 production. Infect Immun 2000;68:3581-6.

13. * Solis-Pereyra B, Aattouri N, Lemonnier D: Role of food in the stimulation of cytokine production. Am J Clin Nutr 1997;66:521S-525S

14.*Arunachalam K, Gill HS, Chandra RK: Enhancement of natural immune function by dietary consumption of Bifidobacterium lactis (HN019). Eur J Clin Nutr 2000;54:263-7.

15.*De Simone C, Vesely R, Bianchi Salvadori B, Jirillo E: The role of probiotics in modulation of the immune system in man and in animals. Int J Immunother 1993;IX:23-8

16. $*$ Schiffrin EJ, Rochat F, Link-Amster H, Aeschlimann JM, Donnet-Hughes A: Immunomodulation of human blood cells following the ingestion of lactic acid bacteria. J Dairy Sci 1995; 78:491-7.

17.*Spanhaak S, Havenaar R, Schaafsma G: The effect of consumption of milk fermented by Lactobacillus casei strain Shirota on the intestinal microflora and immune parameters in humans. Eur J Clin Nutr 1998;52:899-907.

18.*Trapp CL, Chang CC, Halpern GM, Keen CL, Gershwin ME: The influence of chronic yoghurt consumption on populations of young and elderly adults. Int J Immunother 1993; IX:53-64.

19.*Donnet-Hughes A, Rochat F, Serrant P, Aeschlimann JM, Schiffrin EJ: Modulation of non specific mechanisms of defense by lactic acid bacteria: effective dose. J Dairy Sci 1999:82:863-9.

20.*Pelto L, Isolauri E, Lilius EM, Nuutila J, Salminen S: Probiotic bacteria down-regulate the milk-induced inflammatory response in milk-hypersensitive subjects but have an immunostimulatory effect in healthy subjects. Clin Exp Allergy 1998:28:1474-9.

21.*He F, Tuomola E, Arvilommi H, Salmonen S: Modulation of humoral immune response through probiotic intake. FEMS Immunol Med Microbiol 2000;29:47-52.

22 Hessle C, Hanson LÅ, Wold AE: Lactobacilli from human gastrointestinal mucosa are strong stimulators of IL-12 production. Clin Exp Immunol 1999;116:276-82. 
23. Hessle $\mathrm{C}$, Hanson $\mathrm{LA}$, Wold AE: Interleukin-10 produced by the innate immune system masks in vitro evidence of acquired T-cell immunity to $\mathrm{E}$. coli. Scand J Immunol 2000;52:13-20.

24. Trinchieri G: Interleukin-12: a cytokine produced by antigen-presenting cells with immunoregulatory functions in the generation of T-helper cells type 1 and cytotoxic lymphocytes. Blood 1994;84:4008-27.

25. D'Andrea A, Aste-Amezaga M, Valiante NM, Ma X, Kubin M, Trinchieri G: Interleukin 10 (IL-10) inhibits human lymphocyte interferon $\gamma$-production by suppressing natural killer cell stimulatory factor/IL-12 synthesis in accessory cells. J Exp Med 1993;178:1041-8.

26. Quan CP, Berneman A, Pires R, Avrameas S, Bouvet JP: Natural polyreactive secretory immunoglobulin. A autoantibodies as a possible barrier to infection in humans. Infect Immun 1997;65:3997-4004.

27. Cebra JJ: Influences of microbiota on intestinal immune system development. Am J Clin Nutr 1999;69:1046S-1051S

28. *Fukushima Y, Kawata Y, Hara H, Terada A, Mitsuoka T: Effect of a probiotic formula on intestinal immunoglobulin A production in healthy children. Int J Food Microbiol 1998;42:39-44

29. Ferguson A, Humphreys KA, Croft NM: Technical report: results of immunological tests on faecal extracts are likely to be extremely misleading. Clin Exp Immunol 1995;99:70-5.

30.*Marteau P, Vaerman JP, Dehennin JP, Bord S, Brassart D, Pochart P, et al: Effects of intrajejunal perfusion and chronic ingestion of Lactobacillus johnsonii strain Lal on serum concentrations and jejunal secretions of immunoglobulins and serum proteins in healthy humans. Gastroenterol Clin Biol 1997;21:293-8.

31. Majamaa $\mathbf{H}$, Isolauri E. Probiotics: A novel approach in the management of food allergy. J Allergy Clin Immunol 1997;99:179-85.

32. ${ }^{*}$ Link-Amster H, Rochat F, Saudan KY, Mignot O, Aeschlimann JM: Modulation of a specific humoral immune response and changes in intestinal flora mediated through fermented milk intake. FEMS Immunol
Med Microbiol 1994;10:55-63.

33.*Isolauri E, Joensuu J, Suomalainen H, Luomala M, Vesikari T: Improved immunogenicity of oral D x RRV reassortant rotavirus vaccine by Lactobacillus casei GG. Vaccine 1995;13:310-2.

34.*Kaila M, Isolauri E, Soppi E, Virtanen E, Laine S, Arvilommi H. Enhancement of the circulating antibody secreting cell response in human diarrhea by a human Lactobacillus strain. Pediatr Res 1992;32:141-4.

35.*Kaila M, Isolauri E, Saxelin M, Arvilommi H, Vesikari T: Viable versus inactivated lactobacillus strain GG in acute rotavirus diarrhoea. Arch Dis Child 1995;72:51-3.

36.*Malin M, Suomalainen H, Saxelin M, Isolauri E: Promotion of IgA immune response in patients with Crohn's disease by oral bacteriotherapy with Lactobacillus GG. Ann Nutr Metab 1996;40:137-45. finns i tabell saknas i text

37. Czerkinsky C, Svennerholm AM, Quiding M, Jonsson R, Holmgren J Antibody-producing cells in peripheral blood and salivary glands after ora cholera vaccination of humans. Infect Immun 1991;59:996-1001.

38. Kantele A, Arvilommi H, Jokinen I: Specific immunoglobulin-secreting human blood cells after peroral vaccination against Salmonella typhi. J Infect Dis 1986;153:1126-31.

39. Kantele AM, Takanen R, Arvilommi H: Immune response to acute diarrhea seen as circulating antibody-secreting cells. J Infect Dis 1988;158:1011-6.

40. Wennerås C, Qadri F, Bardhan PK, Sack RB, Svennerholm AM: Intestinal immune responses in patients infected with enterotoxigenic Escherichia coli and in vaccines. Infect Immun 1999;67:6234-41.

41. Herías MV, Midtvedt T, Hanson LA, Wold AE: Increased antibody prod uction against gut-colonizing Escherichia coli in the presence of the anaerobic bacterium Peptostreptococcus. Scand I Immunol 1998:48:277-82.

42. Wold AE, Dahlgren UI, Hanson LA, Mattsby-Baltzer I, Midvetdt T Difference between bacterial and food antigens in mucosal immunogenicity. Infect Immun 1989;57:2666-73.

Table 1. Immune effects of probiotics, columns 1-6.

\begin{tabular}{|c|c|c|c|c|c|}
\hline 1. Ref. & 2. Main hypothesis & 3. Intervention method & 4. Study design & $\begin{array}{l}\text { 5. Recruitment/ } \\
\text { Inclusion criteria }\end{array}$ & $\begin{array}{l}\text { 6. Exclusion } \\
\text { criteria }\end{array}$ \\
\hline Halpern et al (8) & $\begin{array}{l}\text { Yoghurt consumption } \\
\text { increases IFN- } \gamma \text { production } \\
\text { by blood cells }\end{array}$ & $\begin{array}{l}\text { 1) } 450 \mathrm{~g} \text { yoghurt/d } \\
\text { 2) } 450 \mathrm{~g} \text { heat-treated } \\
\text { yoghurt/d } \\
\text { 3) No yoghurt products }\end{array}$ & $\mathrm{RCT}$ & $\begin{array}{l}\text { Students and university } \\
\text { employees and other } \\
\text { people } \\
20-40 \text { years of age }\end{array}$ & $\begin{array}{l}\text { 1) Medications that } \\
\text { would alter } \\
\text { measured } \\
\text { parameters } \\
\text { 2) Extreme diets } \\
\text { 3) Recent illness }\end{array}$ \\
\hline Wheeler et al (9) & $\begin{array}{l}\text { Yoghurt consumption } \\
\text { increases IFN- } \gamma \text { and IL-2 } \\
\text { production by blood } \\
\text { lymphocytes and response } \\
\text { to systemic and peroral } \\
\text { vaccination }\end{array}$ & $\begin{array}{l}\text { 1) Yoghurt (Danone) } 225 \\
\text { g/d containing } 3 \times 10 \mathrm{e} 8 \\
\text { CFU/g of Lactobacillus } \\
\text { bulgaricus }\left(7 \times 10^{10}\right. \\
\text { CFU/d) and } 4 \times 10^{8} \\
\text { Streptococcus } \\
\text { thermophilus }\left(9 \times 10^{7} / \mathrm{d}\right) \\
\text { 2) } 225 \mathrm{~g} \text { milk/d }\end{array}$ & $\begin{array}{l}\mathrm{RCT} \\
\text { Cross-over }\end{array}$ & $\begin{array}{l}\text { 2) Clinical history of } \\
\text { asthma or } \\
\text { rhinoconjunctivitis } \\
\text { 3) Positive skin prick } \\
\text { test }(>3 \times 3 \mathrm{~mm} \\
\text { greater than saline } \\
\text { control) } \\
31 \text { years of age }(21-47)\end{array}$ & $\begin{array}{l}\text { Allergy or other } \\
\text { intolerance to milk } \\
\text { products }\end{array}$ \\
\hline Wheeler et al (10) & $\begin{array}{l}\text { Consumption of yoghurt } \\
\text { with } L \text {. acidophilus } \\
\text { improves clinical } \\
\text { symptoms in asthma }\end{array}$ & $\begin{array}{l}\text { 1) } 450 \mathrm{~g} / \mathrm{d} \text { live yoghurt } \\
\left(3 \times 10^{8} \text { S. thermophilus/g }\right. \\
\text { and } 3 \times 10^{8} \\
\text { L. bulgaricus } / \mathrm{g}) \text { with } \\
8 \times 10^{8} \mathrm{CFU} / \mathrm{g} \\
\text { L. acidophilus }(1.5 \mathrm{x} \\
\left.10^{11} \text { L. acidophilus } / \mathrm{d}\right) \\
\text { 2) } 450 \mathrm{~g} / \mathrm{d} \text { of live yoghurt }\end{array}$ & $\begin{array}{l}\text { RCT } \\
\text { Cross-over, double-blind }\end{array}$ & $\begin{array}{l}\text { 1) } \begin{array}{l}\text { Clinical history of } \\
\text { asthma and/or } \\
\text { rhinitis }\end{array} \\
\text { 2) Positive prick test } \\
(>3 \times 3 \text { mm larger } \\
\text { than saline control) } \\
\text { 3) } \mathrm{FEV}_{1.0} 40-80 \% \text { of } \\
\text { normal and >15\% } \\
\text { improvement upon } \\
\beta 1 \text { stimulant } \\
\text { inhalation } \\
\text { 33 years of age (13-45) }\end{array}$ & $\begin{array}{l}\text { 1) Allergy or other } \\
\text { intolerance to } \\
\text { milk products } \\
\text { now or } \\
\text { previously } \\
\text { 2) Active smoking } \\
\text { last } 3 \text { months } \\
\text { 3) Antibiotic } \\
\text { treatment } \\
\text { 4) Immunotherapy }\end{array}$ \\
\hline Solis-Pereyra et al (13) & $\begin{array}{l}\text { Yoghurt consumption } \\
\text { increases production o } \\
\text { 2'-5' A synthetase in blood } \\
\text { cells }\end{array}$ & $\begin{array}{l}\text { 1) } 250 \mathrm{~g} \text { yoghurt }\left(10^{9}\right. \\
\text { S. thermophilus and } 10^{9} \\
\text { L. bulgaricus } / \mathrm{g}) \\
\text { 2) } 250 \mathrm{~g} \text { milk } \\
\text { 3) } 250 \mathrm{~g} \text { yoghurt } / \mathrm{d}, 15 \text { days } \\
\text { 4) } 250 \mathrm{~g} \text { milk/d, } 15 \mathrm{~d}\end{array}$ & $\begin{array}{l}\text { RCT } \\
\text { Parallel group } \\
\text { (group } 1 \text { and 2) } \\
\text { Cross-over } \\
\text { (group } 3 \text { and 4) }\end{array}$ & $25 \pm 7$ years of age & $\begin{array}{l}\text { 1) Somatic disease } \\
\text { 2) Medication }\end{array}$ \\
\hline Arunachalam et al (14) & $\begin{array}{l}\text { Intake of Bifidobacterium } \\
\text { lactis indreases IFN- } \alpha \\
\text { production, phagocytic } \\
\text { capacity and bactericidal } \\
\text { activity by blood cells }\end{array}$ & $\begin{array}{l}\text { 1) } 180 \mathrm{ml} \times 2 / \text { day milk } \\
\text { containing } \\
\text { Bifidobacterium lactis } \\
\left(\text { daily dose } 3 \times 10^{11} \text { ) }\right. \\
\text { 2) } 180 \mathrm{ml} \times 2 \text { milk }\end{array}$ & RCT & $\begin{array}{l}60-83 \text { years } \\
\text { healthy }\end{array}$ & $\begin{array}{l}\text { 1) History of } \\
\text { chronic or } \\
\text { debilitating } \\
\text { illness } \\
\text { 2) Milk } \\
\text { intolerance }\end{array}$ \\
\hline
\end{tabular}


Table 1. Immune effects of probiotics, columns 1-6 (cont).

\begin{tabular}{|c|c|c|c|c|c|}
\hline 1. Ref. & 2. Main hypothesis & 3. Intervention method & 4. Study design & $\begin{array}{l}\text { 5. Recruitment/ } \\
\text { Inclusion criteria }\end{array}$ & $\begin{array}{l}\text { 6. Exclusion } \\
\text { criteria }\end{array}$ \\
\hline De Simone et al (15) & $\begin{array}{l}\text { Yoghurt consumption } \\
\text { increases serum IFN- } \gamma \text { and } \\
\text { affects cell populations in } \\
\text { blood }\end{array}$ & $\begin{array}{l}\text { 1) Yoghurt supplemented } \\
\text { with lyophilized } \\
\text { L. bulgaricus and } \\
\text { S. thermophilus ( } 3 \mathrm{x} \\
10^{12} \text { in } 200 \mathrm{~g} \text { !) } \\
\text { 2) } 200 \mathrm{~g} \text { skimmed milk }\end{array}$ & & $\begin{array}{l}\text { Medical students } \\
20-47 \text { years of age }\end{array}$ & \\
\hline Schiffrin et al (16) & $\begin{array}{l}\text { Ingestion of milk } \\
\text { fermented by lactic acid } \\
\text { bacteria increases } \\
\text { phagocytic capacity of } \\
\text { blood cells }\end{array}$ & $\begin{array}{l}120 \mathrm{ml} \text { milk daily } \\
\text { fermented by } \\
\text { Bifdobacterium bifidum } \\
\text { Bb12 }\left(10^{10} \mathrm{CFU} / \mathrm{d}\right) \\
\text { 2) } 120 \mathrm{ml} \text { milk daily } \\
\text { fermented by } \\
\text { L. acidophilus LA1 } \\
\left.\text { (7x } 10^{7} \mathrm{CFU} / \mathrm{d}\right)\end{array}$ & $\begin{array}{l}\text { RT without placebo } \\
\text { group }\end{array}$ & 23-62 years of age & $\begin{array}{l}\text { 1) Low CD4/CD8 } \\
\text { ratio } \\
\text { 2) Activated } \\
\text { T cells in blood } \\
\text { before } \\
\text { treatment }\end{array}$ \\
\hline Spanhaak et al (17) & $\begin{array}{l}\text { Fermented milk containing } \\
L . \text { casei affects NK cell } \\
\text { activity, phagocytosis and } \\
\text { cytokine production in } \\
\text { blood cells }\end{array}$ & $\begin{array}{l}\text { 1) Milk fermented by } \\
\text { L. casei strain Shirota } \\
100 \mathrm{ml} \times 3 / \mathrm{d}\left(3 \times 10^{11}\right. \\
\text { lactobacilli per day) } \\
\text { 2) } \text { Non-fermented milk } \\
100 \mathrm{ml} \mathrm{x} \mathrm{3}\end{array}$ & $\begin{array}{l}\text { RCT } \\
\text { Parallel groups }\end{array}$ & $\begin{array}{l}\text { Male subjects } 40-65 \\
\text { years of age }\end{array}$ & 1) $\begin{array}{l}\text { Obesity } \\
\text { (BMI }>30) \\
\text { 2) }\end{array}$ \\
\hline Trapp et al (18) & $\begin{array}{l}\text { Yoghurt consumption } \\
\text { affects vaccine response } \\
\text { and allergic symptoms }\end{array}$ & $\begin{array}{l}\text { 1) } 200 \mathrm{~g} \text { low-fat yoghurt/d } \\
\text { 2) } 200 \mathrm{~g} \text { heat-inactivated } \\
\text { yoghurt/d } \\
\text { 3) No yoghurt }\end{array}$ & $\begin{array}{l}\text { Groups } 1 \text { and } 2 \\
\text { randomized and double- } \\
\text { blinded, but group } 3 \text { were } \\
\text { those who did not want } \\
\text { to eat yoghurt }\end{array}$ & $\begin{array}{l}\text { College students } 20-40 \\
\text { years of age } \\
\text { Elderly adults } 55-70 \\
\text { years of age }\end{array}$ & $\begin{array}{l}\text { Pregnancy or } \\
\text { nursing, serious } \\
\text { illness past } 5 \text { years, } \\
\text { active infection, } \\
\text { autoimmunity } \\
\text { cancer, liver disease, } \\
\text { lactose intolerance, } \\
\text { malabsorption. } \\
\text { Intake of drugs that } \\
\text { could affect } \\
\text { parameters }\end{array}$ \\
\hline $\begin{array}{l}\text { Donnet-Hughes et al } \\
\text { (19) }\end{array}$ & $\begin{array}{l}\text { Aim to determine the } \\
\text { effective dose of } \\
\text { L. johnsonii La1 for } \\
\text { increasing phagocytosis by } \\
\text { blood cells and to } \\
\text { determine whether the } \\
\text { starter culture has } \\
\text { stimulating effects }\end{array}$ & $\begin{array}{l}\text { 1) } 150 \mathrm{ml} \text { milk product } \\
\text { fermented with } \\
\text { S. thermophilus daily } \\
\text { with addition of } \\
\text { L. johnsonii }(1.5 \mathrm{x} \\
\left.10^{9} / \mathrm{d}\right) \\
\text { 2) } 150 \mathrm{ml} \text { aged product, } \\
\text { containing } 1.5 \times 10^{8} \\
\text { L. johnsonii/d } \\
\text { 3) } 150 \mathrm{ml} \text { milk fermented } \\
\text { with } S \text {. thermophilus only }\end{array}$ & $\begin{array}{l}\text { RCT } \\
\text { Double-blind } \\
\text { Parallel groups }\end{array}$ & 21-57 years & $\begin{array}{ll}\text { 1) } & \text { Antibiotic } \\
\text { treatment } \\
\text { 2) } & \text { Metabolic } \\
\text { disorders } \\
\text { 1) } & \begin{array}{l}\text { Intestinal } \\
\text { disorders }\end{array}\end{array}$ \\
\hline Pelto et al (20) & $\begin{array}{l}\text { Ingestion of milk products } \\
\text { fermented by } \\
\text { Lactobacillus rhamnosus } \\
\text { GG affects receptor } \\
\text { expression on blood PMN } \\
\text { and monocytes }\end{array}$ & $\begin{array}{l}200 \mathrm{ml} \times 2 \text { daily of milk } \\
\text { containing L. rhamnosus } \\
\text { GG }\left(3 \times 10^{8} / \mathrm{d}\right) \\
\text { 3) } \text { Regular milk } \\
200 \mathrm{ml} \mathrm{x} 2\end{array}$ & $\begin{array}{l}\mathrm{RCT} \\
\text { Cross-over, double-blind }\end{array}$ & $\begin{array}{l}\text { Students and staff } \\
\text { tolerant }(9) \text { or non- } \\
\text { tolerant ( } 8 \text { ) to milk upon } \\
\text { blinded challenge. All } \\
\text { had normal lactose } \\
\text { tolerance. } \\
\text { Symptoms: bloating } \\
\text { flatulence, pain and } \\
\text { diarrhea, asthma and } \\
\text { atopic dermatitis (1 pat) } \\
28 \text { years of age }(22-50)\end{array}$ & Acute infection \\
\hline He et al (21) & $\begin{array}{l}\text { Consumption of } \\
\text { Lactobacillus rhamnosus } \\
\text { GG or Lactococcus lactis } \\
\text { increases antibody } \\
\text { response to oral } S \text {. typhi } \\
\text { vaccination and affects } \\
\text { receptor expression on } \\
\text { blood neutrophils }\end{array}$ & $\begin{array}{ll}\text { 1) } & \text { L. rhamnosus } \mathrm{GG}, \\
& \text { lyophilized, } 4 \times 10^{10} \\
& \mathrm{CFU} / \mathrm{d} \\
\text { 2) } & \text { Lactococcus lactis, } \\
& \text { lyohilized, } 3.4 \times 10^{10} / \mathrm{d} \\
\text { 3) } & \text { Placebo: ethyl cellulose }\end{array}$ & RCT & $\begin{array}{l}\text { Healthy volunteers not } \\
\text { consuming fermented } \\
\text { dairy products }\end{array}$ & 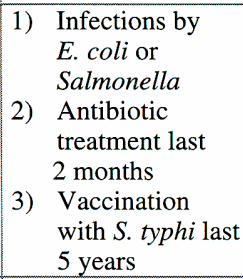 \\
\hline Fukushima et al (28) & $\begin{array}{l}\text { Administration of } \\
\text { forumula containing } \\
\text { bifidobacteria increases } \\
\text { fectal IgA levels and fecal } \\
\text { antibody response to oral } \\
\text { polio virus vaccination }\end{array}$ & $\begin{array}{l}>200 \mathrm{ml} \text { daily of formula } \\
\text { NAN BF (Nestlé) containing } \\
\text { Bifidobacterium lactis (daily } \\
\text { dose }>10^{9} \text { bifidobacteria) }\end{array}$ & $\begin{array}{l}\text { OT } \\
\text { Comparison before- } \\
\text { during treatment, no } \\
\text { control group }\end{array}$ & $\begin{array}{l}\text { Japanese healthy child- } \\
\text { ren } 15-31 \text { months old. } \\
\text { All had completed } \\
\text { routine poliovirus } \\
\text { vaccination by } 12 \text { months } \\
\text { of age }\end{array}$ & \\
\hline
\end{tabular}


Table 1. Immune effects of probiotics, columns 1-6 (cont).

\begin{tabular}{|c|c|c|c|c|c|}
\hline 1. Ref. & 2. Main hypothesis & 3. Intervention method & 4. Study design & $\begin{array}{l}\text { 5. Recruitment/ } \\
\text { Inclusion criteria }\end{array}$ & $\begin{array}{l}\text { 6. Exclusion } \\
\text { criteria }\end{array}$ \\
\hline Marteau et al (30) & $\begin{array}{l}\text { Ingestion of milk } \\
\text { fermented by lactobacilli } \\
\text { increases jejunal secretion } \\
\text { of IgA }\end{array}$ & $\begin{array}{l}\text { 1) } 150 \mathrm{~g} \mathrm{x} 2 \text { of milk } \\
\text { fermented by } \\
\text { L. johnsonii L1 per day } \\
\left(3 \times 10^{10} \mathrm{CFU} / \mathrm{d}\right) \\
\text { 2) Acidified milk of } \\
\text { indistinguishable } \\
\text { appearance in same } \\
\text { quantity }\end{array}$ & RCT double-blind & Healthy volunteers & $\begin{array}{l}\text { 1) } \begin{array}{l}\text { History of } \\
\text { immunologic, } \\
\text { allergic or } \\
\text { digestive } \\
\text { disease }\end{array} \\
\text { 2) } \begin{array}{l}\text { Seropositive for } \\
\text { hepatitis } \mathrm{B}, \mathrm{C} \text { or }\end{array} \\
\text { HIV } \\
\text { 3) Abnormal } \\
\text { clinical } \\
\text { examination }\end{array}$ \\
\hline Majamaa et al (31) & $\begin{array}{l}\text { Ingestion of } L \text {. rhamnosus } \\
\text { GG ameliorates cow's } \\
\text { milk allergy in children }\end{array}$ & $\begin{array}{l}\text { 1) } \begin{array}{l}\text { Hydrolyzed milk } \\
\text { formula with } 5 \times 10^{8}\end{array} \\
\text { CFU/g L. rhamnosus } \\
\text { GG }\left(2-5 \times 10^{11} \mathrm{CFU} / \mathrm{d}\right) \\
\text { 2) } \begin{array}{l}\text { Hydrolysed milk } \\
\text { formula }\end{array}\end{array}$ & $\mathrm{RCT}$ & & \\
\hline Link-Amster et al (32) & $\begin{array}{l}\text { Ingestion of yoghurt with } \\
\text { L. acidophilus Lal and } \\
\text { Bifidobacterium bifidum } \\
\text { Bb12 increases response to } \\
\text { oral vaccination with } \\
\text { attenuated Salmonella } \\
\text { typhi }\end{array}$ & $\begin{array}{l}\text { 1) } 125 \mathrm{~g} \times 3 \text { daily of milk } \\
\text { fermented by mesophilic } \\
\text { streptococci and } \\
\text { S. thermophilus } \\
\text { supplemented with } \\
\text { L. acidophilus and } \\
\text { B. Bifidum }\left(10^{10}-10^{11}\right. \\
\text { CFU/d) } \\
\text { 2) No yoghurt }\end{array}$ & $\begin{array}{l}\text { RCT } \\
\text { No placebo in control } \\
\text { group }\end{array}$ & $19-54$ years of age & $\begin{array}{ll}1) & \text { Lactose } \\
\text { intolerance } \\
\text { 2) } & \text { Recent } \\
& \text { antibiotic } \\
& \text { treatment } \\
\text { 3) } & \text { Previous } \\
& \text { S. typhi } \\
& \text { vaccination last } \\
& 5 \text { years }\end{array}$ \\
\hline Isolauri et al (33) & $\begin{array}{l}\text { L. rhamnosus GG } \\
\text { improves vaccine response } \\
\text { to rotavirus }\end{array}$ & $\begin{array}{l}\text { 1) } 5 \mathrm{ml} \text { water with freeze- } \\
\text { dried L. rhamnosus } \mathrm{GG} \\
\text { twice daily }\left(10^{11} \mathrm{CFU} / \mathrm{d}\right) \\
\text { 2) } \begin{array}{l}\text { Same amount of placebo } \\
\text { (cellulose) }\end{array}\end{array}$ & RCT & $\begin{array}{l}\text { Children } 60-150 \text { days } \\
\text { (mean } 4.1 \text { months) }\end{array}$ & Not stated \\
\hline Kaila et al (34) & $\begin{array}{l}\text { Intake of } L . \text { rhamnosus } \\
\text { GG stumulates antibody } \\
\text { response to rotavirus } \\
\text { infection }\end{array}$ & $\begin{array}{l}\text { 1) } 125 \mathrm{~g} \mathrm{x} 2 \text { per day of } \\
\text { milk product fermented } \\
\text { with } L \text {. rhamnosus } \mathrm{GG} \\
\text { 2) Fermented milk as } \\
\text { above, but pasteurized }\end{array}$ & RCT & $\begin{array}{l}\text { Children with acute } \\
\text { gastroenteritis of } \\
<7 \text { days' duration } \\
\text { admitted to hospital } \\
\text { during rotavirus } \\
\text { epidemic }\end{array}$ & \\
\hline Kaila et al (35) & $\begin{array}{l}\text { Ingestion of live } \\
\text { L. rhamnosus GG is better } \\
\text { than ingestion of dead } \\
\text { bacteria to stimulate } \\
\text { antibody response to } \\
\text { rotavirus in children with } \\
\text { rotavirus diarrhoea }\end{array}$ & $\begin{array}{l}\text { 1) L. rhamnosus GG } \\
\text { lyophilized } 10^{10}-10^{11} \\
\text { CFU/d } \\
\text { 2) Same as above but heat- } \\
\text { treated }\end{array}$ & $\begin{array}{l}\text { RCT } \\
\text { Double-blind }\end{array}$ & $\begin{array}{l}\text { 1) Children with acute } \\
\text { gastroenteritis of } \\
<7 \text { days' duration } \\
\text { admitted to hospital } \\
\text { during rotavirus } \\
\text { epidemic. } \\
\text { 2) <4 years of age } \\
\text { 3) rotavirus positive }\end{array}$ & Not stated \\
\hline Malin et al (36) & $\begin{array}{l}\text { Administration of freeze- } \\
\text { dried } L \text {. rhamnosus GG } \\
\text { increases circulation of } \\
\text { cells producing IgA } \\
\text { antibodies against } \\
\beta \text {-lactoglobulin }\end{array}$ & $\begin{array}{l}10^{10} \mathrm{CFU} \text { freeze-dried } \\
\text { L. rhamnosus GG in liquid } \\
\text { once daily }\end{array}$ & $\begin{array}{l}\text { OT } \\
\text { Response compared } \\
\text { before-during } \\
\text { L. rhamnosus feeding }\end{array}$ & $\begin{array}{l}\text { 1) Crohn's disease } 5-17 \\
\text { years of age of which } \\
\text { half had active } \\
\text { disease } \\
\text { 2) Juvenile chronic } \\
\text { arthritis } 2-14 \text { years of } \\
\text { age, all taking } \\
\text { NSAIDs } \\
\text { 3) Surgery patients } \\
\text { 4-15 years }\end{array}$ & \\
\hline
\end{tabular}


Table 1. Immune effects of probiotics, columns 7-10 (cont).

\begin{tabular}{|c|c|c|c|c|c|c|}
\hline \multirow[t]{2}{*}{ Ref. } & \multirow[t]{2}{*}{ 7. Matching of groups } & \multirow[t]{2}{*}{ 8. Treatment time } & \multirow{2}{*}{$\begin{array}{l}\text { 9. Follow up after treatment } \\
\text { (if any, e.g. persistence of } \\
\text { probiotic organism in faeces, } \\
\text { recurrence of symptoms) }\end{array}$} & \multicolumn{3}{|c|}{ 10. Number of subjects/patients } \\
\hline & & & & $\begin{array}{l}\text { Number } \\
\text { starting }\end{array}$ & $\begin{array}{l}\text { Number ending } \\
\text { experimental } \\
\text { period }\end{array}$ & $\begin{array}{l}\text { Number } \\
\text { followed up } \\
\text { (if any) }\end{array}$ \\
\hline 8 & & 4 months & & 68 & & 67 \\
\hline 9 & $\begin{array}{l}\text { Nine persons were randomised to } \\
\text { consuming milk first, while } 11 \\
\text { were randomised to consuming } \\
\text { yoghurt first }\end{array}$ & $\begin{array}{l}1 \text { month on each diet, } \\
\text { both preceded by } 2 \mathrm{w} \\
\text { wash-out period }\end{array}$ & & 21 & 1 & 20 \\
\hline 10 & & $\begin{array}{l}1 \text { month on each diet, } \\
\text { both preceded by } 2 \\
\text { wkwash-out period }\end{array}$ & & 16 & 1 & 15 \\
\hline 13 & & $\begin{array}{l}\text { 1+2: } 1 \text { day } \\
3+4: 15 \text { days } \\
\text { preceded by abstaining } \\
\text { from yoghurt or cheese } \\
\text { for } 15 \mathrm{~d}\end{array}$ & & $\begin{array}{l}13 \text { (group } 1+2) \\
8 \text { cross-over }\end{array}$ & & \\
\hline 14 & & 6 weeks & 6 weeks & 25 & & \\
\hline 15 & & $28 \mathrm{~d}$ & & & & \\
\hline 16 & $\begin{array}{l}\text { L. acidophilus group slightly } \\
\text { higher phagocytic index before } \\
\text { treatment ( } 45 \% \text { vs } 42 \%, \mathrm{p}=0.051 \text { ) }\end{array}$ & $\begin{array}{l}3 \text { weeks } \\
\text { preceded by } 3 \text { weeks } \\
\text { wash-out }\end{array}$ & 6 weeks & $\begin{array}{l}28 \\
(12 \text { female, } \\
16 \text { male })\end{array}$ & & \\
\hline 17 & & $\begin{array}{l}4 \text { weeks } \\
\text { preceded by } 8 \text { weeks } \\
\text { wash-out period }\end{array}$ & 2 weeks follow-up & 20 & & 20 \\
\hline 18 & $\begin{array}{l}\text { Good between } 1 \text { and } 2 \text {, but group } 3 \\
\text { may have different life-style }\end{array}$ & 1 year & & $\begin{array}{l}123 \\
60 \text { young, } \\
63 \text { elderly }\end{array}$ & & 98 \\
\hline 20 & $\begin{array}{l}\text { Statistics used do not take } \\
\text { advantage of cross-over design }\end{array}$ & $\begin{array}{l}1 \text { week treatment } \\
\text { preceded by } 1 \text { week } \\
\text { wash-out }\end{array}$ & & 17 & & 17 \\
\hline 19 & $\begin{array}{l}\text { Randomisation procedure } \\
\text { awkwardly described: "randomly } \\
\text { distributed according to age, sex, } \\
\text { and faecal lactobacilli into three } \\
\text { groups" } \\
\text { Treatment groups had lower initial } \\
\text { phagocytic activity of blood cells }\end{array}$ & $\begin{array}{l}3 \text { weeks } \\
\text { preceded by } 3 \text { weeks } \\
\text { wash-out period }\end{array}$ & $\begin{array}{l}6 \text { weeks } \\
\text { (150 ml milk per day, no } \\
\text { fermented products) }\end{array}$ & 42 & & 42 \\
\hline 21 & & $\begin{array}{l}7 \text { days } \\
\text { vaccination days } 1,3,5\end{array}$ & Blood samples day $-1,+7$ & 30 & & 30 \\
\hline 28 & & $\begin{array}{l}20 \text { days } \\
\text { preceded by } 10 \text { days } \\
\text { without yoghurt or } \\
\text { other foods containing } \\
\text { viable microbes }\end{array}$ & 7 days after ceased intake & 7 & & \\
\hline 30 & $\begin{array}{l}\text { Serum IgA concentration before } \\
\text { treatment twice as high in placebo } \\
\text { as in intervention group }\end{array}$ & 28 days & & $\begin{array}{l}12 \\
(6 \text { intervention } \\
\text { group, } 6 \text { control } \\
\text { group) }\end{array}$ & & \\
\hline 31 & $\begin{array}{l}\text { Treatment group had higher } \\
\text { SCORAD of allergic symptoms } \\
\text { before treatment }\end{array}$ & 1 month & 2 months & 31 & $\begin{array}{l}4 \\
\text { no positive } \\
\text { reaction to } \\
\text { provocation with } \\
\text { cow's milk }\end{array}$ & 27 \\
\hline 32 & & $\begin{array}{l}3 \text { weeks preceded by } 2 \\
\text { weeks wash-out }\end{array}$ & 3 weeks & 30 & & \\
\hline 33 & $\begin{array}{l}\text { No data on breastfeeding. No data } \\
\text { given on how many children that } \\
\text { were examined! }\end{array}$ & 5 days & 30 days & $60 ? ?$ & $? ?$ & $? ?$ \\
\hline 34 & No data concerning breast-feeding! & 5 days & $\begin{array}{l}3 \text { weeks measurement of } \\
\text { antibody response to rotavirus }\end{array}$ & 44 & $\begin{array}{l}5 \text { who did not have } \\
\text { rotavirus diarrhoea }\end{array}$ & $\begin{array}{l}39 \\
22 \text { treatment } \\
\text { group } \\
17 \text { control } \\
\text { group }\end{array}$ \\
\hline 35 & No data on breast-feeding & 5 days & $\begin{array}{l}1 \text { month. Serum antibodies } \\
\text { measured on admission and one } \\
\text { month later }\end{array}$ & 26 & & $\begin{array}{l}26(13 \text { expt } \\
\text { group, } 143 \\
\text { control group })\end{array}$ \\
\hline 36 & $\begin{array}{l}\text { Much fewer control children than } \\
\text { children with inflammatory } \\
\text { diseases. Significances can, thus, } \\
\text { not be compared as done }\end{array}$ & 10 days & & $\begin{array}{l}14 \text { Crohn's } \\
9 \text { JCA } \\
7 \text { controls }\end{array}$ & & \\
\hline
\end{tabular}


Table 1. Immune effects of probiotics, columns 11-14 (cont).

\begin{tabular}{|c|c|c|c|c|c|c|c|c|c|}
\hline \multirow[t]{3}{*}{ Ref. } & \multicolumn{6}{|c|}{ 11. Results } & \multirow{3}{*}{$\begin{array}{l}12 . \\
\text { a. Side effects } \\
\text { b. Compliance } \\
\text { measure }\end{array}$} & \multirow{3}{*}{$\begin{array}{l}\text { 13. Evaluation } \\
\text { of quality }\end{array}$} & \multirow{3}{*}{$\begin{array}{l}\text { 14. Concluding remarks } \\
\text { - strength of evidence }\end{array}$} \\
\hline & \multicolumn{2}{|c|}{ Main outcome } & \multicolumn{2}{|c|}{ Other effects } & \multicolumn{2}{|c|}{ Drop-outs } & & & \\
\hline & Treatment & Control & Treatment & Control & $\begin{array}{c}\text { Treat } \\
\text {-ment }\end{array}$ & $\begin{array}{l}\text { Con- } \\
\text { trol }\end{array}$ & & & \\
\hline 8 & $\begin{array}{l}\text { IFN- } \gamma \text { production } \\
\text { by blood } \\
\text { mononucl. cells: } \\
\text { 1) } 20 \pm 9 \mathrm{U} / \mathrm{ml}\end{array}$ & $\begin{array}{l}\text { 2) } 1.7 \pm 1.3 \mathrm{U} / \mathrm{ml} \\
\text { 3) } 5.2 \pm 3.1\end{array}$ & $\begin{array}{l}\text { No IFN- } \gamma \\
\text { detected in } \\
\text { sera. No } \\
\text { difference in } \\
\text { blood cell } \\
\text { counts }\end{array}$ & $\begin{array}{l}\text { Increased } \\
\text { ionized } \\
\text { calcium in } \\
\text { both yoghurt } \\
\text { groups }\end{array}$ & & $\begin{array}{l}\text { Flatul. 1 } \\
\text { person } \\
\text { in heat- } \\
\text { treated } \\
\text { yoghurt } \\
\text { group }\end{array}$ & $\begin{array}{l}\text { "90\% } \\
\text { compliance" } \\
\text { Not further } \\
\text { specified }\end{array}$ & $\begin{array}{l}++(+) \\
\text { No compliance } \\
\text { measure }\end{array}$ & $\begin{array}{l}++(+) \\
\text { Consumption of live } \\
\text { yoghurt enhances } \\
\text { spontaneous production } \\
\text { of IFN- } \gamma \text { by peripheral } \\
\text { blood lymphocytes }\end{array}$ \\
\hline 9 & $\begin{array}{l}\text { Cytokine } \\
\text { pouduction after } 3 \\
\text { d PHA stimul: } \\
\text { IL-2: } \\
\text { 1) } 88 \text { (pre) --- } \\
106 \text { (post) } \\
\text { 2) } 94 \text { (pre) --- } \\
88 \text { (post) } \\
\text { 1vs2: p=0.09 } \\
\text { IFN- } \gamma \text { : } \\
\text { 1) } 125 \text { (pre) -- } \\
165 \text { (post) } \\
\text { 2) } 139 \text { (pre) -- } \\
154 \text { (post) } \\
\text { 1vs } 2: \text { p=0.24 } \\
\text { PMN oxidative } \\
\text { burst: } \\
\text { 1) } 0.40-0.54 \\
\text { 2) } 0.50-0.53 \\
\text { p=0.16 }\end{array}$ & & $\begin{array}{l}\text { No effect on } \\
\text { serum IgG, } \\
\text { IgM, IgA, } \\
\text { IgE, salivary } \\
\text { S-IgA. No } \\
\text { effect on } \\
\text { blood counts } \\
\text { of CD4, CD8 } \\
\text { or NK cells, } \\
\text { NK cell func- } \\
\text { tion, PHA or } \\
\text { ConA in- } \\
\text { duced proli- } \\
\text { feration. No } \\
\text { effect on } \\
\text { response to } \\
\text { parenteral } \\
\text { pneumo- } \\
\text { coccal or oral } \\
\text { polio vacc. } \\
\end{array}$ & & \begin{tabular}{l|} 
(due \\
to \\
sche- \\
duling \\
con- \\
flicts)
\end{tabular} & & & $\begin{array}{l}+++ \\
\text { Beautiful study }\end{array}$ & $\begin{array}{l}+++ \\
\text { No effect on response to } \\
\text { vaccination } \\
+(+) \\
\text { Discretely (statistically } \\
\text { non-significant) } \\
\text { enhanced IFN- } \gamma \text { and IL- } \\
2 \text { production of blood } \\
\text { lymphocytes and PMN } \\
\text { oxidative burst }\end{array}$ \\
\hline 10 & 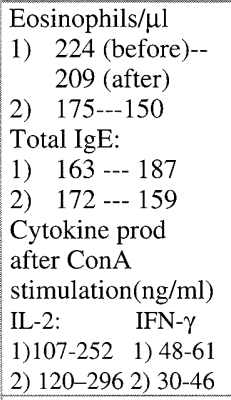 & & $\begin{array}{l}\text { No effect on } \\
\text { clinical } \\
\text { asthma } \\
\text { symptoms } \\
\text { or spiro- } \\
\text { metry values }\end{array}$ & & $\begin{array}{l}1 \text { (due } \\
\text { to } \\
\text { sche- } \\
\text { duling } \\
\text { con- } \\
\text { flicts) }\end{array}$ & & & $\begin{array}{l}++(+) \\
\text { No group not } \\
\text { eating yoghurt }\end{array}$ & $\begin{array}{l}+++ \\
\text { No clinical effect on } \\
\text { asthma by either yoghurt } \\
+(+) \\
\text { Increase (statistical } \\
\text { significance not tested) in } \\
\text { ConA-stimulated } \\
\text { production of IL-2 and } \\
\text { IFN- } \gamma \text { by blood } \\
\text { lymphocytes after } \\
\text { yoghurt consumption }\end{array}$ \\
\hline 13 & $\begin{array}{l}2 '-5 \text { ' A synthetase } \\
\text { in blood cells ( } 24 \mathrm{~h} \\
\text { after ingestion): } \\
\text { 1) } 84(13) \text { before } \\
---196(12) \\
\text { after } \\
\text { 2) } 89(16) \text { before } \\
--102(62) \\
\text { after } \\
\text { ( } \mathrm{p}=0.002 \text { for } \\
1 \text { vs } 2) \\
\text { 3) } 265(33) \\
\text { yoghurt phase } \\
\text { 4) } 192 \text { (milk phase) } \\
\text { p<0.05 }\end{array}$ & & $\begin{array}{l}\text { No increase } \\
\text { of IFN- } \gamma \text {, } \\
\text { IL-1ß or } \\
\text { TNF- } \alpha \text { in } \\
\text { plasma }\end{array}$ & & & & & ++ & $\begin{array}{l}++ \\
\text { Ingestion of yoghurt } \\
\text { induces } 2 \text { ' }-5 \text { A } \\
\text { synthetase in blood } \\
\text { mononuclear cells }\end{array}$ \\
\hline 14 & $\begin{array}{l}\% \text { PMN ingesing } \\
\text { bacteria: } \\
2 \mathrm{x} \text { by } 3 \text { weeks } \\
3 \mathrm{x} \text { by } 6 \text { weeks } \\
\text { IFN- } \alpha \text { production } \\
\text { (PHA stimulation): } \\
3 \mathrm{U} / \mathrm{ml} \text { before- } 10 \mathrm{U} \\
(3 \mathrm{w})\end{array}$ & $\begin{array}{l}1.4 \mathrm{x} \text { by } 3 \text { weeks } \\
1.3 \mathrm{x} \text { by } 6 \text { weeks } \\
4 \mathrm{U} / \mathrm{ml} \text { before - } \\
5 \mathrm{U} / \mathrm{ml}(3 \mathrm{w})\end{array}$ & $\begin{array}{l}\text { Phago- } \\
\text { cytosis still } \\
\text { increased } \\
2.7 \mathrm{x} \\
6 \text { weeks } \\
\text { after ceased } \\
\text { treatment }\end{array}$ & & & & $\begin{array}{l}\text { Strain detected } \\
\text { in stools using } \\
\text { DNA probe, } \\
\text { but no data } \\
\text { shown } \\
\text { "Compliance } \\
\text { was confirmed } \\
\text { by the } \\
\text { subjects"(!) }\end{array}$ & $\begin{array}{l}+ \\
\text { Poorly explained } \\
\text { statistics (effect } \\
\text { in treatment } \\
\text { group compared } \\
\text { "either" with } \\
\text { control group or } \\
\text { with pre-study } \\
\text { values) }\end{array}$ & $\begin{array}{l}+(+) \\
\text { Ingestion of yoghurt with } \\
\text { Bifidobacterium lactis } \\
\text { enhances phagocytosis } \\
\text { by PMN. } \\
\text { Interferon- } \alpha \text { values } \\
\text { extremely low - } \\
\text { biologically } \\
\text { insignificant? }\end{array}$ \\
\hline 15 & $\begin{array}{l}\text { IFN- } \alpha \text { in blood: } \\
\text { 1) } 43 \text { (U/ml?) } \\
\quad \text { before, } 70 \\
\quad \text { (U/ml?) after } \\
\text { B cells in blood: } \\
\text { increase from } 370 \\
\text { to } 500 \text { (unit?) } \\
\text { NK cells: } 450 \\
\text { to } 650\end{array}$ & $\begin{array}{l}\text { Control group } \\
\text { not shown }\end{array}$ & & & & & & $\begin{array}{l}+ \\
\text { Very high } \\
\text { lactobacillus } \\
\text { dose }\end{array}$ & $\begin{array}{l}+ \\
\text { Questionable if IFN- } \gamma \\
\text { can be measured in } \\
\text { serum }\end{array}$ \\
\hline
\end{tabular}


Table 1. Immune effects of probiotics, columns 11-14 (cont).

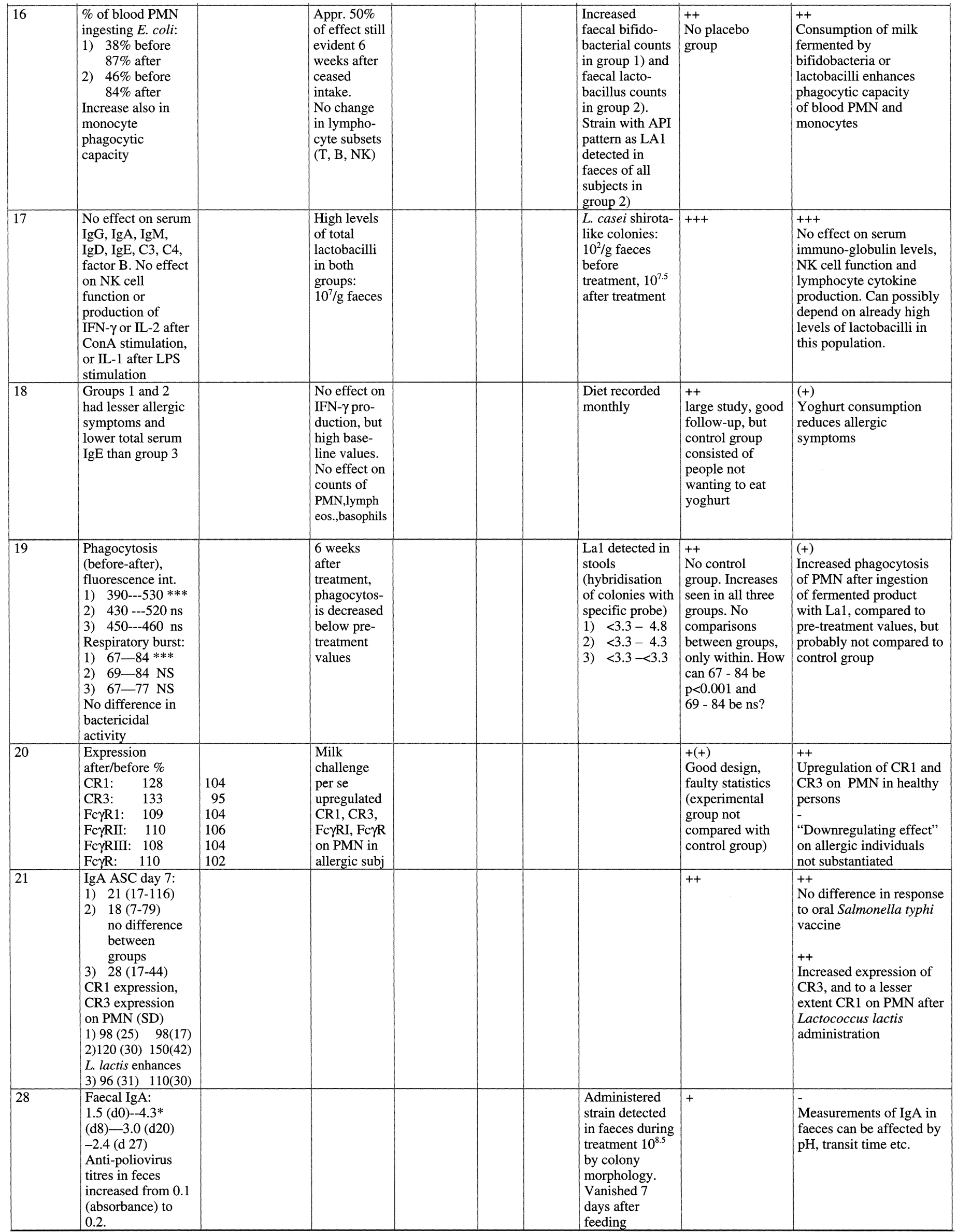


Table 1. Immune effects of probiotics, columns 11-14 (cont).

\begin{tabular}{|c|c|c|c|c|c|c|c|c|}
\hline 30 & $\begin{array}{l}\text { Serum IgA } \\
\text { increased from } \\
1.76 \text { to } 1.85 \mathrm{~g} / \mathrm{l} \text { in } \\
\text { treatment group } \\
\text { (but control group } \\
\text { had } 2.4 \text { before and } \\
\text { after). } \\
\text { No increased } \\
\text { secretion of } \mathrm{IgA} \text {, } \\
\mathrm{SC}, \mathrm{IgG} \text { or } \mathrm{IgM} \text { in } \\
\text { jejunum }\end{array}$ & & $\begin{array}{l}\text { Perfusion of } \\
\text { intestine } \\
\text { with } 10^{7} \\
\text { lactobacilli/ } \\
\text { ml gave } \\
\text { higher } \\
\text { exsudation } \\
\text { of serum } \\
\text { proteins } \\
\text { (ns.) }\end{array}$ & & & & $\begin{array}{l}++(+) \\
\text { Elegant protocol, } \\
\text { Small group }\end{array}$ & $\begin{array}{l}++ \\
\text { No increased production } \\
\text { of secretory } \operatorname{IgA} \text { in } \\
\text { intestine after } \\
\text { consumption of lactic } \\
\text { acid bacteria }\end{array}$ \\
\hline 31 & $\begin{array}{l}\text { SCORAD: } \\
22 \text { (before)-18 (1 } \\
\text { mo) } \\
\alpha 1-A T \text { in feces: } \\
1.4---0.5 \\
\text { TNF- } \alpha \text { in feces: } \\
710---34 \\
\text { ECP in feces: } \\
71-48\end{array}$ & $\begin{array}{l}27---21 \\
1.7---1.7 \\
630--490 \\
77-47\end{array}$ & & & & & $\begin{array}{l}\text { - } \\
\text { Comparisons not } \\
\text { made between } \\
\text { intervention and } \\
\text { control group, } \\
\text { only before-after } \\
\text { treatment }\end{array}$ & $\begin{array}{l}\text { - } \\
\text { No proven effect on } \\
\text { clinicals symptoms } \\
+ \\
\text { Decrease of TNF- } \alpha \text { in } \\
\text { faeces, but survival in } \\
\text { faeces might be } \\
\text { influenced by diet (pH, } \\
\text { water content, transient } \\
\text { time) }\end{array}$ \\
\hline 32 & $\begin{array}{l}\text { Serum IgA titer } \\
\text { Pre: } 25 \\
2 \mathrm{w}: 102 \\
42 \mathrm{~d}: 37 \\
\text { Diff betw. groups } \\
(2 \mathrm{w}): \mathrm{p}=0.04 \\
\text { Control group had } \\
\text { better } \\
\text { response in saliva. } \\
\text { Increased anti- } \\
\text { body response also } \\
\text { to unrelated } \\
\text { antigens }\end{array}$ & $\begin{array}{l}25 \\
62 * \\
28\end{array}$ & $\begin{array}{l}\text { Total serum } \\
\text { IgA } \\
\text { increased } \\
\text { by } 10 \% \\
(1.8-2.0 \\
\text { g/l) during } \\
\text { yoghurt } \\
\text { consump- } \\
\text { tion }\end{array}$ & & & $\begin{array}{l}\text { Faecal } \\
\text { bifidobacterial } \\
\text { and } \\
\text { lactobacillus } \\
\text { counts } \\
\text { increased by } \\
1 \text { log in treat- } \\
\text { ment group }\end{array}$ & $\begin{array}{l}+ \\
\text { lousy vaccine } \\
\text { response }\end{array}$ & $\begin{array}{l}\text { No adjuvant effect } \\
\text { proven. Only minimal } \\
\text { increase in antibody titres } \\
\text { and minimal difference } \\
\text { between yoghurt and } \\
\text { control. Increase also to } \\
\text { unrelated antigens. } \\
\text { Increase in total serum } \\
\text { IgA after youghurt } \\
\text { consumption }\end{array}$ \\
\hline 33 & $\begin{array}{l}\text { Postvaccination } \\
\text { titres: } \\
\text { IgM: } 67(33-136) \\
\text { IgA: } 22(11-43) \\
\text { IgM ASC } \\
\text { before: } 0.3(0.1- \\
\quad 1.1) \\
\text { day } 8: 4.3(1.5-12)\end{array}$ & $\begin{array}{l}26(7-97) p=0.19 \\
6(1-27) p=0.10 \\
0.7(0.1-3.1) \\
0.6(0.1-2.7) \\
p=0.02\end{array}$ & & \begin{tabular}{l|} 
Fever \\
$>38$ \\
$17 \%$ \\
vomi- \\
ting: 2 \\
child- \\
ren
\end{tabular} & $14 \%$ & & & $\begin{array}{l}(+) \\
\text { Minimal effect on } \\
\text { response to oral rotavirus } \\
\text { vaccination. Only IgM } \\
\text { response affected. } \\
\text { No evidence of adjuvant } \\
\text { effect (non-specific } \\
\text { stimulation). }\end{array}$ \\
\hline 34 & $\begin{array}{l}\text { Non-specific } \\
\text { immunoglobulin } \\
\text { secreting cells } \\
\text { twice as many in } \\
\text { GG-fed group } \\
\text { Only } 1 \text { in } \\
\text { treatment and } 2 \text { in } \\
\text { control group had } \\
>10 \text { ASC against } \\
\text { rotavirus }\end{array}$ & & & $\begin{array}{l}6 \\
\text { no } \\
\text { infor } \\
\text { ma- } \\
\text { tion }\end{array}$ & & & $\begin{array}{l}++ \\
\text { for study } \\
- \\
\text { for statistical } \\
\text { evaluation. Too } \\
\text { low cut-off for } \\
\text { response }(0.5 \\
\text { antibody- } \\
\text { secreting } \\
\left.\text { cells } / 10^{6}\right) \\
\end{array}$ & $\begin{array}{l}++ \text { Increase in } \\
\text { immunoglobulin- } \\
\text { secreting cells in blood } \\
\text { (non-specific) } \\
- \\
\text { Increase in response to } \\
\text { rotavirus (no response in } \\
\text { either group). }\end{array}$ \\
\hline 35 & $\begin{array}{l}\text { Antibody response } \\
\text { in serum } \\
\text { Acute: } 0.04(0.01- \\
\quad 0.3) \\
\text { Conval:51(29-87) } \\
\text { "5 times more } \\
\text { IgA-secreting cells } \\
\text { in convalescence } \\
\text { in group 1, but no } \\
\text { data given. }\end{array}$ & $\begin{array}{l}0.1(0.01-0.5) \\
22(12-43) \\
p=0.04\end{array}$ & & & & & $\begin{array}{l}++ \\
\text { for study } \\
(+) \\
\text { for statistical } \\
\text { evaluation }\end{array}$ & $\begin{array}{l}\text { Very weak antibody } \\
\text { response in both groups. } \\
\text { Too low cut-off for } \\
\text { definition of response } \\
\left(0.5 \text { cells per } 10^{6}\right)\end{array}$ \\
\hline 36 & $\begin{array}{l}\text { Minimal increase } \\
\text { in IgA ASC to } \\
\text { food antigens in } \\
\text { Crohn group with } \\
\text { lactobacillus } \\
\text { treatment: } \\
\text { BLG: } 0.2-1.4 \\
\text { spots/10 } \\
\text { Casein: } 0.3-1.0 \\
\text { Gliadin } 0.7-1.6\end{array}$ & & & & & & $\begin{array}{l}\text { + for study } \\
\text { - for statistical } \\
\text { evaluation }\end{array}$ & $\begin{array}{l}\text { Minimal increase in IgA- } \\
\text { secreting cells producing } \\
\text { antibodies to food } \\
\text { proteins. Clinical } \\
\text { significance? }\end{array}$ \\
\hline
\end{tabular}

